\title{
The Science of Parting: Eliade, Iranian Shamanism, and the View from Tomis
}

\section{Citation}

Russell, James. 2010. The science of parting: Eliade, Iranian shamanism, and the view from Tomis. Studia Asiatica 11(1): 89-97.

\section{Permanent link}

http://nrs.harvard.edu/urn-3:HUL.InstRepos:10880589

\section{Terms of Use}

This article was downloaded from Harvard University's DASH repository, and is made available under the terms and conditions applicable to Open Access Policy Articles, as set forth at http:// nrs.harvard.edu/urn-3:HUL.InstRepos:dash.current.terms-of-use\#OAP

\section{Share Your Story}

The Harvard community has made this article openly available.

Please share how this access benefits you. Submit a story. 


\title{
THE SCIENCE OF PARTING: ELIADE, IRANIAN SHAMANISM, AND THE VIEW FROM TOMIS
}

\author{
James R. RUSSELL \\ Harvard University, Cambridge, $M A$
}

Я изучил науку расставанья

-Осип Мандельштам, «Tristia»

\begin{abstract}
Mircea Eliade created from a heterogeneous and rich dossier the study of Shamanism as a focused discipline: his scholarly studies and metaphysical or mystical novellas reflect aspects of particular shamanistic narratives in pre-Islamic Iranian religion, in a manner that illuminates also Eliade's important concerns as a Romanian, and his existential situation as an exile. All these concerns are related to each other, historically and as relevant features of the phenomenology of shamanism itself.
\end{abstract}

In shamanism the function of a priestly practitioner of religious ritual intersects with that of the protagonist of a heroic epic or character in a folktale. The shaman, who is recognized as the holder of a cultic office, generally wears a garment necessary to his activity that is considered an animate appendage to his being. He recites poems, sometimes cosmological, sometimes of his own composition or elaboration, which narrate his deeds. These usually consist of an out-of-body spiritual descent or flight into an otherworld where, with the assistance of animal or other spirits - or by compelling them - he acquires esoteric knowledge or effects the cure of a disease. Then he returns. The shaman is, even if the holder of a hereditary office, often an alienated individual, even a member of an outcast class. The process of initiation involves a traumatically violent symbolic dismemberment. He is thus a loner; and his activity is more action - the accomplishing of a quest - than the passive prayer one might otherwise associate with the religious. This lone questing hero overcomes figures out puzzles, overcomes obstacles, and vanquishes an adversary, like the main character in an epic or folktale; but he steps into the mythological plot without being fictionalized, as it were, himself. And he bests the dragon, not with a sword, but by means of his magical incantations. Shamanism is the main aspect of religious practice of some traditions; in Zoroastrian and Manichaean Iran it was one of several.

The Sasanian high priest Kartîr's shamanistic quests through the worlds of the afterlife drew upon the ancient precedents of Jāmāspa, some aspects of the Ayādgār $\bar{\imath}$ Zarēerān, and particularly the Ard̄ Virāz nāmag; his multiple, illustrated inscriptions of them accomplished the propagandistic purpose of official magic, of religious advertisement. This suggests that the Zoroastrian establishment was reacting to a serious challenge in a similar

Institute for the History of Religions Romanian Academy www.ihr-acad.ro 
vein. This was posed, not by Christianity — his successor Ādurbād $\overline{1}$ Amahraspandān's vernacular credo Nām stāyishn and the Pahlavi catechism $\check{C} \bar{\imath}$ dag andarz $\bar{l}$ pōryōtkeshān were to be the answer to the Nicene Creedbut by Manichaeism. The famous episode of Mānī's elevation of king Mihrshāh can be seen as shamanistic, and the vision of the Manichaean heaven and hell described in the hymn cycles Angad rōshnān and Huyādagmān were impressive enough to be depicted on funerary bas-reliefs in China centuries after the Apostle of Light's own parinirvāna.

Two narratives from the Iranian sphere that have the hallmarks of cosmological and quest tales subjected secondarily to shamanistic recasting and religious use invite consideration. The first would belong to a Zoroastrian milieu. In "The Devil and God: Prehistory of the Romanian Folk Cosmogony," the third chapter of Zalmoxis, Eliade studied a myth in which God asks a lone bird associated with the power of evil to fetch soil from the sea bottom so He may create the Earth. The myth suggests that God was not capable of creating the world Himself and required the assistance of either Satanael or an intermediary. Eliade cites the well-known Armenian and Manichaean allusions to a Zoroastrian myth about the demon Mahmī, who supposedly taught Ohrmazd to create light; and he duly points out the probable Iranian provenance of the dualistic motif in the legend. He supports a diffusionist hypothesis, deriving the mythologem from a primordial model in Central Asia; but supposes also that the Iranized pattern reinforced a myth already existent in the Thraco-Dacian milieu; it survived the Christianization of the early Romanians because it provided a folk-cosmological explanation of the question of evil. Eliade claimed that the myth itself is not attested in a Zoroastrian text; however it seems possible that the Bundahishn contains a Zoroastrian and fully dualistic refraction of it: Ohrmazd invited Ahreman to assist him in making the world. The evil spirit refused, and then invaded it in the form of a serpent, puncturing the cosmic egg at the sea bottom and then rushing up into the floating disk of the earth, which fled from him and thereby formed the mountains. This myth of the ébgad, or incursion, of the evil one answers for the Zoroastrians the question Unde malum? whilst differently distributing the elements of the myth Eliade has analyzed. The cosmology of the Bundahishn would seem to have co-opted and altered a myth that in its original form compromises the creative powers of Ahura Mazda.

The myth in its original form is attested in Turco-Mongol tradition, where the creator god is called by the name Kurbystan - most likely a loan from Iranian urmayzdan-, "belonging to Ahura Mazda" — and his evil adversary is Erlik Khan. There is also, apparently, a shamanistic variant which recreates the cosmological setting but changes the purpose and events, and replaces one of the characters. In a Mongolian ritual song recorded by Heissig, it is a shaman who approaches the axial tree of the world on whose branches the Garuda perches - this is the powerful ancient Indian bird who is associated with the naggas. By his magical prowess the shaman acquires the assistance of the bird. Armenian magicians of the mediaeval period used 


\section{THE SCIENCE OF PARTING: \\ ELIADE, IRANIAN SHAMANISM, AND THE VIEW FROM TOMIS}

to employ in a ritual for healing a sick client the text of a talismanic scroll, in whose earliest version three angels approach an uncanny, wingless eagle (Armenian artsiv, a very early Iranian loan) capable of vanquishing serpents (the word used is another Iranian loan, vishap, a kind of submarine dragon) - seated on a branchless tree in the middle of the universe. The ritual was believed to be most effective on a Friday, especially Good Friday. I have argued that this mythological theme was borrowed in the oldest of the Russian ballads called byliny: that of Il'ya Muromets and the NightingaleRobber (Илья Муромеи и Соловей-разбойник). In the latter, the folk hero travels on Easter Sunday with preternatural speed to the court of prince Vladimir at Kiev, having vowed not to shed blood when overcoming obstacles in his path. This seems but a distant echo of the shamanic or magical refraction of the myth, where the practitioner employs his spells and cunning, for in the event Il'ya does slay the mighty and uncanny Nightingale-robber, who is perched on two trees. One need not adhere strictly to a diffusionist method to accept that the Armenian Christian magical spell has its origin in a shamanistic elaboration of the myth of the bird in the primordial ocean. The ultimate source would have been Central Asia; the path of transmission, most likely, would have traversed Iran. Thus the mythologem that the Zoroastrian divines recast would have persisted independently in the context of Iranian folk shamanism, where the Garuda would have been an arozifya-; and the nāgas, vīshäpas. ${ }^{1}$

The second narrative to be considered has affinities to one of Eliade's marvelous mystical novellas. Pelerina (1975), translated as "The Cape", has in Romanian the specific overtone of the vestment of the peregrinus. The pilgrim is Zevedei, whose fifteen years of political activity were followed by fifteen of imprisonment: a kind of latter-day ordeal of shamanistic enlightenment equivalent to the lifetime of Christ and thus also indicative of a movement from physical genesis through the apogenesis of death into spiritual rebirth. (In "Youth Without Youth", Eliade's character, an elderly scholar, is struck by lightning and restored to youth: here the motif of shamanic dismemberment is even more explicit. Eliade's frequent

\footnotetext{
${ }^{1}$ See on the transmission of Iranian dualistic mythology into the cultures of Slavic-speaking peoples and their Finno-Ugrian compatriots J.R. Russell, "The Rime of the Book of the Dove (Stikh o Golubinoi knige): From Zoroastrian cosmology and Armenian heresiography to the Russian novel," in Christine Allison, Anke Joisten-Pruschke, and Antje Wendtland, eds., From Daena to Din: Religion, Kultur und Sprache in der iranischen Welt, Wiesbaden: Harrassowitz, 2009, pp. 141-208 (Festschrift Prof. Dr. Philip Kreyenbroek). On the Nightingale-Robber and the Armenian material see J.R. Russell, “Solov'i, solov'i," St. Nersess Theological Review 10 (2005), pp. 77-139 (published in Russian in Rossiya XXI, 2006. 4, Moscow, pp. 156197.)
} 
chronologies of Christmas and Easter in reverse order also indicate the theme of apogenesis.) Zevedei's garb - a cape bearing the traces of preCommunist epaulettes - attracts the unwelcome attention of the Securitate, who implicate him in the dissemination of issues of Scinteia back-dated three years (to 1966, a significant date for Eliade), in which the venerable Party slogan has been subversively rephrased as "Dreamers of the world, unite!" Christ's "poor in spirit" are encoded into the text; and "providence" replaces the word "provenance". These references are taken by the narrator to refer to Parsifal's quest for the chalice of the holy grail. Zevedei's cape marks him as a questing stranger, a pilgrim from another age. The cape, taking the shape of his true form, defines also his essential belonging to a different, better dispensation.

The overall structure of the story, and its strange details, remind one of a short Syriac poem embedded in the Acts of Thomas called the Hymn of the Pearl or the Hymn of the Soul. The milieu is geographically and socially that of Arsacid Parthia, and a number of key terms are Middle Iranian; and in the absence of a provenance, some students of the work have sought authorship in the providentially imperfectly documented Bardaisan of Edessa. In brief, the king of the East sends his son to recover the pearl that is held captive by a dragon in the sea of Egypt. The prince departs, but at the inn (Syriac eshpezā, from Parthian ispinzh) in Egypt he is drugged and falls asleep, despite the counsel of a noble youth $(\bar{a} z \bar{a} t)$ from his homeland. A letter in the form of an eagle from his father reminds him of his quest and summons him to fight, that he may be inscribed in the Book of Heroes. The prince then employs magical incantations (the verb employed is a derivative of Persian magush) to vanquish the dragon, recovers the pearl, and returns home to the royal court of kind and vaspuhrän; at the gates of the East his robe comes to him. Some twenty of the poem's hundred-odd lines are devoted to a description of the latter. It is the prince's true eidolon and bears the visage of the king of kings. It glitters with gems, the motions of gnosis stir upon it, and the robe sings to him, rejoicing in their reunion.

The poem's elements and structure are those of the traditional heroic epic in which a young warrior ventures forth on a quest, suffers perils and reversals, overcomes them, and slays a dragon. The Iranian trappings are cues to the audience to expect a familiar entertainment - but the preacher of the Gnostic, probably Manichaean, message of the Hymn achieves the effect of surprise by playing on that very expectation to deliver a radically different meaning. The prince does not slay the dragon with a sword; he puts a spell on him. Far from becoming an adult by affirming his place as a warrior in the world, he frees himself from the mire of a cosmos of lies and departs from it, donning the robe that is a reflection of his true self and an emblem of his rejection of physical life. The dragon's subjects are unable to drug him. Now the shamanistic song also employs this morphology of the heroic poem, in which the shaman as hero undertakes his otherworld journey in the manner of a quest, while substituting, as we have seen, magical operations for warfare. So the Hymn of the Pearl seems to be a heroic poem 
THE SCIENCE OF PARTING:

ELIADE, IRANIAN SHAMANISM, AND THE VIEW FROM TOMIS

reconfigured as a Manichaean sermon; and the Manichaeans, like the Zoroastrians, retained some vestiges of shamanism which they employed - as the rivalry of Mānī and Kartīr suggests - for propagandistic purposes.

In Eliade's story, Bucharest under the Communists is the dragon's inn; the police, the monster's accomplices; and propaganda is the potation that stupefies. But Zevedei, attired in the pilgrim's cape of his true self and alien origin, defeats the dragon by magian formulas - the subversion of the clichés of Scinteia. There are other possible traces in Eliade's work of Manichaeism in general and the Syriac hymn in particular: in "Nineteen Roses", for instance, the hero discovers he has a son whom he does not know, who is aware his father tried once to stage a play on Orpheus' descent into the underworld. This enigmatic yet close relationship recalls the Manichaean spirit twin; and in the same story Niculina wears a special, exotic dress while reciting a Syrian spell. Why did Eliade, a gifted prose writer, focus so intently on these particular topics; and why is he so cryptic - why do they require decoding? As to the latter question, Eliade writes in his autobiography: "It seemed to me that this dialectics of hierophanies constituted - though camouflaged - the exemplary model of every human existence." That is, divinity is immanent, but it conceals itself. The purpose of the educational process of this life is to discover it through spiritual and intellectual striving and insight. Subtlety and inference, to the point of using sheer wordplay as a defensive weapon, are a strategy of dealing with totalitarianism most recently - and more traditionally belong to the Mioriţa complex that Eliade defined and studied in Romanian culture. "Literature I can write only in Romanian, the language in which I dream," Eliade once declared: of all forms of expression the dream is the most secretive of all, the most veiled in symbols: indeed, Iranian $r \bar{a} z$, "secret", is borrowed into Armenian as eraz, "dream". Dreams are hyper-mioritic, as it were; and equally they are the vehicle, often, of religious vision, including shamanistic initiation. But why did Eliade evince, in his treatment of shamanistic phenomena, a particular interest in their expression in the preIslamic culture of Iran?

Herodotus and subsequent writers present the Zalmoxis cult as a religion whose founder was a shaman-philosopher-hero-king whose cosmological, eschatological, and moral doctrines were sufficiently profound as to serve the Romanized Dacians of the third century of the Christian era as a proparatio evangelica: the Gospel of redemption and rebirth easily embraced the getas tous athanatizontas. There is, as one might expect of any traditional culture, a strong pagan substratum in Romanian folk beliefpossession by Sânziana (i.e., Sancta Diana, the Thraco-Dacian Bendis whom we meet in the first book of the Republic of Plato), and the shamanistic căluşari, are the most relevant when one considers the shamanistic aspect of the Zalmoxis cult. Zalmoxis was specifically hailed as a religious figure parallel and akin to Zarathustra at the time of the Dacian revival in Romanian scholarship. The Iranian prophet, one need scarcely be reminded, 
had since the Renaissance gradually acquired the status of a hero figure of an extra-Biblical prisca theologia. At first this fictionalized Zoroaster was employed to undermine the dogma of the Catholic Church; as European local nationalisms gained strength, the Iranian prophet became the paragon of an Aryan ethos intended to overcome the slave mentality tendentiously ascribed to the Christian faith in general and to its Jewish origins in particular.

The Daco-Thracians, whom Ovid regarded as kin in every way to the Sarmatians and Scythians of the Black Sea littoral, might then be blood relatives of the Iranian prophet. In the course of forging an Iranian cultural kinship or patrimony for his Dacian ancestors that might at the same time bestow the charisma of antique precedent upon the cultic brotherhood of the Legionaries of the Archangel Michael, Eliade accepted uncritically the scholarship of his friend, the Iranist Stig Wikander. The latter's chief contribution was a hypothetical construction of Iranian Männerbünde whose young initiates were hooligans (a key word in Romanian literature from Eliade in the 1930's down to Norman Manea's memoirs) who swilled soma and acted with the amoral abandon of werewolves. Wikander and Eliade accepted as realia of the institution the vulpine totem of the province of Hyrcania and the ostensibly vulpine symbolism of an Iranian war banner. By adopting the incautious misreading of an Old Persian epithet as haumavarka instead of haumavarga, Eliade was able to characterize the Dacians' Saka neighbors as ambrosia-imbibing lycanthropes; so that when on firmer ground he observed that the Dacian ethnonym itself contains an old word for "wolf", he could present a chain of kinship from Avesta to Saka to Dacian that is tenuous at best. The concept of an occult band of young, berserk males found a ready application under fascism; but in the Zoroastrian texts these mairyas are considered inimical to the message of the Prophet $a b$ initio. It is impossible to square Männerbund with Mazdaism: the fictionalized Zarathustra of Nietzsche was beyond good and evil; but the singular message of the Zarathustra of the Avestan canon is that good and evil are so existentially different as to preclude the possibility of such transcendence.

Norman Manea has asserted that it would be vulgar to assess Eliade's scholarship through the prism of his politics; but Adriana Berger, in her study of the latter, has demonstrated how the refraction of learning through politics creates distortion that impairs scholarship. Chronology is an important factor in Eliade's mystic stories: particular years and festivals seem to exist outside of the flow of the time-space continuum, and this reminds one of the way a shaman can in his trance transcends linear time by entering suspended animation, a ritual death, and acting in the unmoving, primordial present of the Otherworld. It is telling, then, that one such fixed time to which Eliade returns several times in his prose is the year 1938, when Codreanu's supporters were violently suppressed by king Carol II's government and Eliade himself spent several months in detention. This was for him a traumatic and transforming turning point: though he was to serve 


\section{THE SCIENCE OF PARTING: \\ ELIADE, IRANIAN SHAMANISM, AND THE VIEW FROM TOMIS}

in the foreign ministry under the Iron Guardist Antonescu régime that had overthrown the monarchy, 1938 was the point at which the prewar world ended and the prospect of exile became clear. One must not presume to stand in judgement of Eliade, though. He did not take part in the sanguinary, Männerbundist initiatory rites of the Legionaries, and in later years claimed to have been repelled by the extreme violence of the Iron Guard's pogroms in 1941. Perhaps he was: it can be argued that not everyone made the gradual transition from the virulent social anti-Semitism of the 1930's to the eliminationist violence of the Holocaust. That does not make the picture less tragic. The Romanian Jewish author Joseph Hechter, who wrote under the nom de plume of Mihail Sebastian, leaves no doubt in his diaries of the 1930's that his dear friend Mircea shared anti-Semitic prejudices common throughout Europe at the time and felt right-wing nationalism best served Romania in her precarious position. For his part, Eliade avoided meeting Sebastian during a wartime mission home to Bucharest: he knew this would hurt Sebastian; but believed such a meeting would have endangered the latter.

Romania for world culture must evoke the Tristia of Ovid. It was an island of Latinity in the Balkans; a bastion of Orthodoxy in the chains of Ottoman oppression; and many of its most creative minds have endured the pain of flight. Ya izuchil nauku rasstavan'ya, "I've mastered the science of parting," wrote Mandelstam in his own Tristia; and when one considers the legend of Zarathustra's grievous departure from his people and his wandering, and the sojourn of Zalmoxis in the household of Pythagoras and his loneliness even after his nostos amongst his own, then the biographies of the shaman-visionaries Eliade studied may be seen as studies in exile. The shaman himself, for all the social sanctioning that validates his practice, generally exhibits the neurotic traits of an individual alienated by different markers, often deviant sexuality, from the community. His very practice is a departure, whether a psychanodia or descensus ad inferos. But for it to be successful, he has to return with the goods, as it were, a successful Orpheus - or Odysseus (whose wanderings also included a visit to Hades). "Every exile is a Ulysses traveling toward Ithaca... toward the center," Eliade wrote; and in his scholarship and belles lettres he accomplished an imaginal return to the land from which he had fled into exile. Ovid plaintively asks in Tristia ex Ponto, Quod mihi vobiscum est infelix cura, libelli? For Eliade, books were the means of regaining lost Tomis: he had learnt the science of parting.

In the work of Eliade's disciple, the late Ioan Culianu, the questions of shamanism, and of exile, are refracted through a different prism. Where Eliade accepted an essentially diffusionist model of shamanism, one which reinforced, whether by deliberation or fortuity, an ideologically driven concept of Romanian ethnogenesis and cultural identity, Culianu considered the phenomenon an expression of a cast of religious imagination liable independently to originate in human cultures. In the Iranian case, Culianu 
tended to reject the diffusionist idea of a Zoroastrian source of contiguous dualistic systems, such as that encountered in Manichaeism. Culianu wrote in depth on one of the most perceptive students of Manichaeism, Hans Jonas, who analyzes the Hymn of the Pearl in his important book, The Gnostic Religion. The Romanian exile scholar in Chicago must have felt an affinity for the German refugee of an earlier generation: Jonas had been a pupil of Martin Heidegger, but he rejected the latter's fascism and the philosophical stances consonant with it. In particular, Jonas rejected Heidegger's idea of the "destinings" of Being - Christianity consists, Jonas argued, precisely in deliverance from destiny and fate. The essential action of conscious being is not the experience of some heroic ecstatic moment, but the exercise of concern, which is the first principle of freedom. Freedom has as its concomitants love and pity, which must take place in the context of concerned involvement with others, rather than the transcendence of good and evil in heroic isolation or social absorption in some mass will to power.

Both Eliade and Culianu seem to have considered magical operations real in effect, but their thinking on this issue diverges, as well. For the former, shamanism and magic work because there is a spirit world. For the latter, they work because they create a mode of thinking which acts as a self-fulfilling prophecy in the human apperception of external reality; and they fire their symbolism with the energy of desire, co-opting in particular the components of eroticism. One can thus trace the image of Zarathustra from the prisca theologia of Ficino, Pico, and Bruno down to the Aryan model, as noted above; or, along the lines of Culianu's work, one can analyze the same forms of Renaissance magic and find their descendants in the seductive techniques of Fascist propaganda (in this regard, Borges' story "Tlön, Uqbar, and Orbis Tertius" served as an inspiration for Culianu's prose) and capitalist advertising. Culianu, like his fellow exiles Andrei Codrescu and Norman Manea, learnt a different science of parting, whose trajectory, as Manea put it, is not of nation and bloodline and force, but from the tragic experience of the labor camp of Transnistria to Trans-tristia - to a cosmopolitan embrace of the existential exilic state. He quotes Joyce, "I will not serve that in which I no longer believe, whether it call itself my home, my fatherland, or my church, and I will try to express myself in some mode of life or art as freely as I can and as wholly as I can, using for my defense the only arms I allow myself to use: silence, exile, and cunning." The genuine Zarathustra, who left his clan and turned against his ancestral religion, and then composed the sustrained, intricate poetic revelation of the Gäthās, might have spoken much this way himself. And in the end Professor Mircea Eliade, the great scholar and artist whose virtual free Romania was cunningly encrypted and boldly argued in exile, might have inscribed the words of Stephen Daedalus on his escutcheon too, alongside the proud declaration in the language of his dreams. Visatori din toate ţarile, uniţi vă! 